\title{
Breeding silage maize with brown-midrib genes. Feeding value and biochemical characteristics
}

\author{
Y Barrière ${ }^{1 *}$, O Argillier ${ }^{1}, \mathrm{~B}$ Chabbert $^{2}, \mathrm{MT}$ Tollier $^{2}$, B Monties ${ }^{2}$ \\ 'INRA, Station d'Amélioration des Plantes Fourragères, F86600 Lusignan; \\ ${ }^{2}$ INRA-INA, Laboratoire de Chimie Biologique, F78850 Thiverval-Grignon, France
}

(Received 5 July 1993; accepted 16 November 1993)

\begin{abstract}
Summary - The effects of the maize brown-midrib genes $b m 3$ and $b m 1$ on feeding value and agronomic traits were investigated by animal studies and biochemical approaches. When sheep were fed $b m 3$ silage, an increase in digestibility was observed, equal to 2.4 points for digestibility of organic matter (DOM), and 8.1 points for digestibility of crude fiber (DCF). Phenotypic variation was reduced for all observed traits of $b m 3$ hybrids. This allowed the assumption that the $b m 3$ gene acted by levelling to a similar value of almost $74 \%$ DOM, quite independently of the original value of the normal counterpart. The bm 1 hybrids were intermediate between normal and bm3 ones for DOM, DCF and intake, but the dry matter yield was not reduced for $b m 1$ hybrids. From experiments with young bulls, feed efficiency of INRA260 bm 1 was not significantly improved, compared with normal INRA260, but INRA260 bm3 was a lot more efficient. Despite its lower adverse effect on agronomic characteristics of hybrids, the $b m 1$ allele did not appear to be of any interest in improving the silage maize feed efficiency. Variations for lignin content due to the $b m 3$ gene was similar for the 3 hybrids studied, despite their variation for susceptibility to root and stalk lodging. Ratios and content of alkali-labile hydroxycinnamic acids behaved similarly for the 3 hybrids, with a low yield of para-coumaric acid. Structural studies of lignin, after thioacidolysis, strengthened the results previously obtained, with a clear decrease of syringyl units, and the occurrence of the 5-hydroxyguaiacyl residue. The lignin of $b m 3$ genotypes also appeared as a more condensed polymer than that of the normal types. The decrease of lignin content was observed in only $1 \mathrm{bm} 1$ hybrid and appeared the same between normal and $b m 1$ hybrids as between normal and bm3 hybrids. The lower yield of para-coumaric acid, and the equal yield of ferulic acid after alkaline hydrolysis of $b m 1$ material were in good agreement with previous work. After thioacidolysis, the release of monomeric syringyl units was similar between $b m 1$ and $b m 3$, about $30 \%$ of the normal counterpart. However, it was very different for guaiacyl units, with a large decrease of the release of these units from the bm1 hybrid. The ratio between syringyl and guaiacyl units was about 0.3 for $b m 3$ hybrids and about 1.3 for the $b m 1$ hybrid. The lignin of this $b m 1$ hybrid appeared as a very condensed polymer compared with the normal type. A large variation for digestibility was also found among normal hybrids. However, inbred lines inducing high digestibility often included unfavorable agronomic traits, such as poor yield, susceptibility to lodging or stalk rot. Second or third cycle lines following pedigree breeding might combine all traits, even if stalk standability and stalk digestibility are partly antagonistic. This method may be considered as easier than the bm3 method, but at present, the 2 ways are probably complementary, and worth investigating for improving silage digestibility, and simultaneously increasing knowledge on silage maize digestibility.
\end{abstract}

Zea mays = maize $/$ feeding value $/$ brown-midrib $/ \mathrm{bm} 1 / \mathrm{bm} 3 /$ lignin $/$ hydroxycinnamic acids $/$ thioacid olysis / syringyl/guaiacyl

Résumé - Utilisation des gènes brown-midrib pour la sélection du maïs ensilage. Variabilité pour la valeur alimentaire et les caractéristiques biochimiques. Les effets des gènes brown-midrib bm1 et bm3 sur la valeur alimentaire et les caractéristiques agronomiques d'hybrides de mails ont été étudiés à partir d'essais sur animaux et de mesures de composition biochimique de la lignine. Sur moutons, les hybrides bm3 conduisent à une amélioration moyenne de la digestibilité de la matière organique (DOM)

* Correspondence and reprints. 
voisine de 2,4 et de celle de la cellulose brute (DCF) voisine de 8,1 points. La variabilité phénotypique est nettement réduite entre hybrides bm3, comparée à celle observée pour les quasi isogéniques normaux, pour la quasi-totalité des caractères étudiès. En particulier, il semble que la présence du gène bm3 conduise à augmenter la DOM des hybrides à une valeur proche de $74 \%$, quel que soit le niveau de digestibilité de l'hybride normal de départ. Les hybrides bm1 se situent de façon intermédiaire entre les formes normales et bm3, sauf pour la productivité en biomasse qui est équivalente à celle des normaux. Mais des essais de croissance comparée de taurillons nourris avec des ensilages de maïs INRA260, INRA260 bm1 et INRA260 bm3 montrent que la forme bm1 ne permet pas, contrairement à la forme bm3, une amélioration notable des performances animales. La réduction de teneur en lignine a été semblable pour les 3 hybrides bm3 étudiés, alors que ces hybrides présentaient des différences importantes de sensibilité à la verse ou à la casse. Les teneurs et rapports entre acides hydroxycinnamiques libérés après hydrolyse alcaline étaient semblables chez les 3 hybrides, avec une libération faible d'acide para-coumarique caractéristique des génotypes bm3. La thioacydolyse confirme que la lignine des plantes bm3 est plus pauvre en unités syringyl, avec, de plus, la présence d'une unité 5-hydroxyguaiacyl. La lignine des plantes bm3 est un polymère plus condensé que la lignine des plantes normales. Observée à partir d'un seul hybride bm1, la diminution de la teneur en lignine a été semblable chez les plantes bm1 et bm3. Après thioacidolyse, la libération d'unités syringyl était équivalente entre bm1 et bm3. Mais la libération d'unité guaiacyl était beaucoup plus faible pour la lignine des plantes bm1, avec des rapports syringyl/guaiacyl voisins de 0,3 pour les bm3 et de 1,3 pour les bm1. La lignine des plantes bm1 est également un polymère hautement condensé. Une variabilité importante pour la DOM et la DCF existe aussi entre hybrides normaux. Toutefois, les hybrides les plus digestibles présentent en général des défauts agronomiques importants, qu'il sera sans doute possible de corriger au niveau de lignées de second ou troisième cycle. Actuellement, on peut considérer que les voies normales et bm3 sont deux approches complémentaires de l'amélioration et de la compréhension de la digestibilité du maïs ensilage.

Zea mays = maïs $/$ ensilage $/$ valeur alimentaire $/$ brown-midrib $/ \mathrm{bm} 1 / \mathrm{bm} 3 /$ lignine $/$ acides $h y d r o x y c i n-$ namiques / thioacidolyse/syringyl/guaiacyl

\section{INTRODUCTION}

Silage maize is a very important forage crop, providing a roughage with a high energy content suitable for high milk or meat yielding livestock. An improvement in feeding value may be sought either from genetic variation between normal genotypes, or by using brown-midrib genes which have major effects on digestibility, intake and feed efficiency of the silage. A similar approach was investigated by improving the protein content and quality of maize grain, with or without using Opaque 2 material (Dudley et al, 1974; Vasal et. al, 1980).

Genetic variation for the in vivo digestibility of organic matter (DOM), and for the in vivo digestibility of crude fiber (DCF) of normal maize hybrids was previously reported by Barrière et al (1992). Differences between early or medium early hybrids ranged from about 64 to $76 \%$ for DOM and from 45 to $64 \%$ for DCF. Because higher values were observed with the experimental hybrids, the range of variation is a little lower when studying only registered varieties.

Brown-midrib genes have drastic effects on maize silage quality, and a review on brown- midrib genes in maize was recently reported (Barrière and Argillier, 1993). About 30 years ago, it was established that the 4 non-allelic brown-midrib genes reduce lignin content and alter lignin composition, as well as cell-walllinked phenolic acids of the stalk and leaves of maize. The bm3 gene appeared as more efficient in reducing the lignin content with an average reduction nearing $45 \%$. Experiments carried out with ruminants fed bm3 maize silage showed an increase in the digestibility of organic matter and cell-wall constituents and an increase of the dry matter intake. Most often, when the forage to concentrate ratio was high, a significant increase of feed efficiency, estimated as average daily gain or milk yield per $\mathrm{kg}$ of intake feed, was reported with $b m 3$ isogenic hybrids compared with normal ones. However, brown-midrib hybrids, and more specifically $b m 3$ ones, also appeared to have lower agronomic values, for instance in dry matter yield, earliness and standability. The brown-midrib genes also affect the chemical composition of lignins. From studies undertaken with near isogenic lines or hybrids, it was reported, first with $b m 1$, and later, and more extensively, with $b m 3$, that the alkaline hydrolysis of cell walls from normal plants released about twice as much para-coumaric 
acid, than the brown midribs. After thioacidolysis (Lapierre et al, 1986), there was a lower release of total monomeric units from lignin, with a lower ratio between syringyl and guaiacyl units in bm3 genotypes.

It is therefore of great importance, for silage maize breeding purposes: i) to compare, on a larger scale of genetic background, the effect of the brown-midrib genes (mostly bm3) on feeding value and agronomic traits; ii) to study the feeding value and biochemical characteristics of more recent $b m 3$ hybrids bred for improved agronomic behavior, as opposed to the older ones; iii) to study the possibility of pointing out biochemical criteria for understanding and breeding for quality traits, from comparisons of cell-wall characteristics between normal and brown-midrib hybribs; and iv) to evaluate the interest of brown-midrib material, compared with the available variability within normal hybrids.

\section{MATERIALS AND METHODS}

\section{Breeding brown-midrib genotypes}

Most of the $b m 1$ and $b m 3$ genotypes used in these experiments were obtained at INRA Lusignan from at least 6 and often 7 backcrosses to each parent inbred line. Moreover, the first assessments made on the recent Adonis bm3 hybrid began after only 4 backcrosses for the female parent line, but after an intensive selection of these progenies for their per se value in nursery conditions. No specific data on lodging or stalk-rot susceptibility was available from the experimental plots used for making silage. The behavior of the hybrid was already known from observations in numerous fields and small plots.

\section{Measurements of feeding value}

Measurements of feeding value were performed as previously described by Barrière et al (1992). During at least $2 \mathrm{yr}$, except when seeds were unavailable, 2 plots measuring $250 \mathrm{~m}^{2}$ were cropped for each hybrid studied, and 2 corresponding minisilos were made, in order to obtain a dry-matter content of the silage nearing 30 and $35 \%$, independently of the earliness of the hybrids. Six Texel castrated male sheep, individually housed in digestibility crates, were fed twice a day one of these silages ad libitum in order to get around a $15 \%$ refusal. Minerals were added, and the nitrogen content of the diet was balanced with urea. Crudefiber content was estimated by the Weende method on mixed samples from each day and each animal. Voluntary intakes of maize silage were related to the metabolic weight of animals ( $\mathrm{g} \quad \mathrm{DM} / \mathrm{kg}$ weight ${ }^{0.75}$ ). The digestibility of organic matter and that of crude fiber (DOM, DCF, \%) were computed from forage offered, refusals and faeces, on an average value of $5 \mathrm{~d}$ and 6 sheêp. A total of 988 silage maize measurements of feeding value have been performed since 1969 , including comparisons between normal and brown-midrib hybrids. Average values for each trait were computed through an usual analysis of variance, over $23 \mathrm{yr}, 2$ stages of harvest and 184 genotypes, as previously described by Barrière et al (1992). The years were statistically connected through replicates of hybrids over periods, and through the use of 4 hybrids as partly successive controls (LG11, INRA260, INRA258 and Dea). Since assessments of adjusted and comparable mean values were only statistically reliable when the calculation was performed from the complete data base, it was not possible to make direct statistical tests of normal and bm3 effects, such as Fisher tests. Because of the disequilibrium of the data, and lack of a lot of genotype $\times$ year combinations, genotype $\times$ year interactions would have been unreliably tested, and were not computed. Registered hybrids tested under a confidentiality clause were referred to as Rh. For experimental hybrids (Ex), an equivalent of the year of registration was estimated according to the year of the release of the constituent lines, allowing comparisons of experimental and registered hybrids of the same generation.

Experiments were also carried out on young bulls, which were fed silage maize $a b$ libitum, and the same amount of concentrate (soya cake) regardless of whether normal or brown-midrib maize silage was offered. These experiments lasted about 5 months. Detailed procedures have previously been published by Malterre et al (1985). Charolais bulls were fed INRA260 and INRA260 $b m 1$ silage maize, whereas Salers, Charolais $\times$ Salers and Charolais $\times$ Normand bulls were fed INRA260 and INRA260 bm3 silage maize.

\section{Biochemical investigations}

Biochemical measurements were made on the 3 normal and bm3 hybrids LG11, Puma and Adonis grown in Lusignan. Comparisons of $\mathrm{F} 7 \times \mathrm{F} 2$ normal and $b m 1$ were made from plants grown in a greenhouse in Grignon. This single hybrid is the female of the 3-way hybrids used for animal comparisons of normal, bm 1 and $b m 3$ hybrids. Stalks of the plants were harvested at the grain maturity stage, and air dried. Internodes were ground in a mill with 
rotating blades. The ground materials were soxhlet extracted with toluene/ethanol $(2: 1)$ and ethanol, followed by water to obtain the cell-wall residue. The lignin content of maize bottom, middle and top internodes was estimated, in duplicate, by the modified Klason procedure (Effland, 1977). Phenolic acids, released from cell walls after alkali treatment, were extracted and detected according to Chabbert et al (1993), in duplicate. Monomer composition of lignin was determined by thioacidolysis according to Lapierre et al (1986). Monomeric products, recovered by dichloromethane extraction, were analyzed by capillary column CPG of their trimethylsilyl derivatives according to Chabbert et al (1993), in 3 independent experiments.

\section{RESULTS AND DISCUSSION}

\section{Agronomic and animal results}

\section{Normal and bm 3 hybrids}

When sheep were fed silages (table I), the increase in digestibilities between normal hybrids and their isogenic counterparts was equal to 2.4 points for DOM and 8.1 points for DCF, therefore in line with previously reported results. As a consequence, the aver-

Table I. Feeding and agronomic traits of normal and bm3 hybrids.

\begin{tabular}{|c|c|c|c|c|c|c|c|c|c|c|c|c|c|c|}
\hline Hybrid & $\begin{array}{l}\text { Year of } \\
\text { registration }\end{array}$ & $\begin{array}{l}\text { No of } \\
\text { silos }\end{array}$ & $\begin{array}{c}D O M \\
\%\end{array}$ & $c l$ & $\begin{array}{c}D C F \\
\%\end{array}$ & $c l$ & $\begin{array}{l}\text { Crude } \\
\text { fiber } \\
\% D M\end{array}$ & $c l$ & $\begin{array}{c}\text { Intake } \\
g / \\
k g w^{0.75}\end{array}$ & $c l$ & $\begin{array}{l}\text { Yield } \\
t \quad D M / \\
h a\end{array}$ & cl & $\begin{array}{l}\text { Grain } \\
\% D M\end{array}$ & cl \\
\hline INRA310 & 1968 & 20 & 69.6 & 0.9 & 52.1 & 2.6 & 19.0 & 0.8 & 53.4 & 2.4 & 12.2 & 0.7 & 46.6 & 1.9 \\
\hline INRA310 $b \mathrm{~m} 3$ & & 2 & 74.5 & 2.6 & 63.1 & 7.5 & 11.9 & 2.4 & 53.1 & 7.0 & 11.3 & 2.1 & 40.5 & 5.5 \\
\hline INRA400 & 1967 & 27 & 69.9 & 0.8 & 53.0 & 2.3 & 19.2 & 0.7 & 50.1 & 2.1 & 13.0 & 0.7 & 41.0 & 1.7 \\
\hline INRA400 $\mathrm{bm} 3$ & & 5 & 72.8 & 1.7 & 63.0 & 4.8 & 18.6 & 1.5 & 56.3 & 4.5 & 12.3 & 1.4 & 32.6 & 3.5 \\
\hline F564 ×W401 & Ex 1975 & 2 & 70.1 & 2.6 & 55.6 & 7.5 & 20.4 & 2.4 & 43.4 & 7.0 & 14.5 & 2.1 & 44.5 & 5.5 \\
\hline $\mathrm{F} 564 \times \mathrm{W} 401 \mathrm{bm} 3$ & & 2 & 73.1 & 2.6 & 68.2 & 7.5 & 23.0 & 2.4 & 42.9 & 7.0 & 11.6 & 2.1 & 38.2 & 5.5 \\
\hline Adonis & 1984 & 6 & 70.3 & 1.6 & 51.9 & 4.7 & 19.4 & 1.5 & 44.6 & 4.4 & 16.0 & 1.3 & 39.4 & 3.5 \\
\hline Adonis $b m 3$ & & 4 & 72.0 & 1.9 & 58.9 & 5.5 & 19.3 & 1.8 & 51.2 & 5.1 & 14.1 & 1.6 & 37.1 & 4.0 \\
\hline INRA302 & 1976 & 8 & 70.4 & 1.4 & 46.9 & 3.9 & 17.9 & 1.3 & 50.4 & 3.7 & 12.5 & 1.1 & 42.6 & 2.9 \\
\hline INRA302 $\mathrm{bm} 3$ & & 7 & 72.4 & 1.4 & 62.0 & 4.1 & 19.0 & 1.3 & 56.4 & 3.8 & 11.0 & 1.2 & 42.5 & 3.0 \\
\hline INRA260 & 1961 & 51 & 70.8 & 0.6 & 54.0 & 1.7 & 18.5 & 0.5 & 50.6 & 1.5 & 12.6 & 0.5 & 42.5 & 1.2 \\
\hline INRA260 $\mathrm{bm} 3$ & & 27 & 73.3 & 0.8 & 62.2 & 2.2 & 18.9 & 0.7 & 51.4 & 2.1 & 11.7 & 0.6 & 42.1 & 1.7 \\
\hline LG11 & 1970 & 74 & 71.0 & 0.5 & 53.1 & 1.4 & 18.3 & 0.4 & 52.0 & 1.3 & 12.3 & 0.4 & 43.4 & 1.0 \\
\hline LG11 bm3 & & 28 & 74.0 & 0.7 & 64.4 & 2.0 & 18.7 & 0.7 & 51.8 & 1.9 & 11.3 & 0.6 & 42.7 & 1.5 \\
\hline Fronica & 1971 & 2 & 71.4 & 2.6 & 55.3 & 7.5 & 20.3 & 2.4 & & 7.0 & 12.8 & 2.1 & 44.3 & 5.5 \\
\hline Fronica $b m 3$ & & 2 & 74.6 & 2.6 & 64.2 & 7.5 & 19.8 & 2.4 & 50.7 & 7.0 & 11.2 & 2.1 & 44.5 & 5.5 \\
\hline INRA 188 & 1974 & 20 & 71.6 & 0.9 & 54.5 & 2.5 & 18.2 & 0.8 & 51.4 & 2.3 & 11.6 & 0.7 & 43.4 & 1.8 \\
\hline INRA188 bm3 & & 14 & 74.0 & 1.0 & 61.1 & 2.9 & 18.5 & 0.9 & 53.3 & 2.7 & 11.9 & 0.8 & 42.1 & 2.2 \\
\hline Puma & 1982 & 4 & 71.7 & 1.9 & 51.5 & 5.5 & 18.0 & 1.8 & 52.1 & 5.1 & 11.5 & 1.6 & 45.1 & 4.0 \\
\hline Puma bm3 & & 4 & 73.6 & 1.9 & 58.6 & 5.5 & 17.9 & 1.8 & 53.8 & 5.1 & 11.4 & 1.6 & 38.8 & 4.0 \\
\hline INRA240 & 1972 & 4 & 72.6 & 1.8 & 59.9 & 5.3 & 17.9 & 1.7 & 56.8 & 4.9 & 12.0 & 1.5 & 48.5 & 3.9 \\
\hline INRA240 $\mathrm{bm} 3$ & & 8 & 75.0 & 1.3 & 60.9 & 3.8 & 17.9 & 1.2 & 53.9 & 3.5 & 11.6 & 1.1 & 42.7 & 2.8 \\
\hline INRA258 & 1958 & 40 & 72.9 & 0.6 & 57.5 & 1.8 & 18.8 & 0.6 & 53.2 & 1.7 & 12.0 & 0.5 & 42.5 & 1.4 \\
\hline INRA258 bm3 & & 4 & 74.0 & 1.9 & 63.9 & 5.4 & 17.9 & 1.7 & 57.5 & 5.0 & 11.3 & 1.5 & 46.8 & 4.0 \\
\hline Brufix & 1977 & 4 & 72.9 & 1.9 & 61.9 & 5.5 & 16.8 & 1.8 & 46.9 & 5.1 & 8.6 & 1.6 & 42.4 & 4.0 \\
\hline Brufix $b m 3$ & & 4 & 74.8 & 1.9 & 67.0 & 5.5 & 17.6 & 1.8 & 45.3 & 5.1 & 10.7 & 1.6 & 43.0 & 4.0 \\
\hline F7 ×Ep1 & Ex 1958 & 14 & 73.0 & 1.1 & 56.6 & 3.2 & 17.5 & 1.0 & 56.7 & 3.0 & 10.6 & 0.9 & 45.2 & 2.4 \\
\hline $\mathrm{F} 7 \times E \mathrm{E} 1 \quad b m 3$ & & 2 & 73.5 & 2.7 & 60.7 & 7.8 & 17.6 & 2.5 & 61.0 & 7.2 & 11.9 & 2.2 & 35.8 & 5.8 \\
\hline Mean normal & & 276 & 71.3 & 0.2 & 54.6 & 0.6 & 18.6 & 0.2 & & 0.6 & 12.4 & 0.2 & 43.7 & 0.4 \\
\hline Mean $b m 3$ & & 113 & 73.7 & 0.3 & 62.7 & 1.0 & $18.3^{*}$ & 0.3 & 52.8 & 0.9 & 11.7 & 0.3 & 40.7 & 0.7 \\
\hline Variance normal & & & 1.4 & & 14.1 & & 1.0 & & 15.4 & & 2.9 & & 5.2 & \\
\hline Variance $b m 3$ & & & 0.8 & & 7.5 & & $5.3^{*}$ & & 21.6 & & 0.7 & & 14.2 & \\
\hline
\end{tabular}

DOM: digestibility of organic matter; DCF: digestibility of crude fiber; $\mathrm{cl}=$ confidence limit.

"Mean and variance were respectively 18.8 and 2.0 when excluding INRA310 bm3. 
age increase of nutritive value was equal to $0.04 \mathrm{UFL} / \mathrm{kg}$ DM (UFL= net energy feed unit for milk production, Jarrige, 1988), equivalent to the net energy requirement for yielding $1.5 \mathrm{~kg}$ of fat-corrected milk when the daily silage maize intake by a cow was about $16.5 \mathrm{~kg}$. There were large differences between normal hybrids and their respective $b m 3$ counterparts, from 0.5 to 4.8 points for DOM, and 1.0 to 15.2 points for DCF, even if these results have to be considered in the light of their respective confidence limits. Even if it was not always the case, the hybrids with lower values of digestibility often appeared to be those that were the most improved by the $b m 3$ allele. Crude-fiber content of normal and bm3 hybrids was similar, except for an unlikely and abnormally low value for INRA $310 \mathrm{bm}$. Intake was on average only a little higher for bm3 hybrids, and appeared to be less improved than expected from previous results with bm3 hybrids. There were also great differences between hybrids; intake was $15 \%$ higher for Adonis bm3 as compared to normal Adonis, but there was no difference between normal and bm3 types of LG11. However, with cattle (bulls, dairy cows), a significantly higher intake of $b m 3$ silage was observed by Hoden et al (1985) and Malterre et al (1985), even though differences were either non-existent or small in sheep. These results illustrated once again that the ranking of diets for voluntary intake is often precluded from animals other than the class of livestock and/or the physiological stage for which they are intended (Chesnot and Martin-Rosset, 1985; Moran et al, 1988).

The average biomass dry-matter (DM) yield of maize was only $5 \%(0.6 \mathrm{t} / \mathrm{ha})$ lower for $b m 3$ hybrids, but the decrease reached $12 \%$ $(1.9 \mathrm{t} / \mathrm{ha})$ with respect to the highest yielding normal hybrid Adonis. Average grain content was 3.4 points lower for $b m 3$ hybrids, but with a large variation between hybrids, from 0.2 point higher to 9.4 points lower. Because grain is the main digestible part of the plant, the decrease in grain content strengthened the improvement of stover digestibility due to the $b m 3$ gene. The variances of phenotypic means were also different for normal and bm3 hybrids. Variation was clearly reduced for DOM and DCF between bm3 hybrids, allowing the assumption that the bm3 gene acted by levelling these values. Variation for yield was also reduced for bm3 hybrids, but this yield decrease was not of equal importance be- tween hybrids. Variations for grain content, intake and possibly crude-fiber content were higher for $b m 3$ hybrids than for their normal counterparts. Thus, according to the various observed traits, different levels of interaction were noted between the $b m 3$ gene and the normal genetic germplasms. Similar effects of specific interaction of the bm3 gene and normal genomes were discussed by Miku et al (1980) for lignin content, Gupta et al (1988) for plant biochemical composition and in vitro digestibility of dry matter, and Gentinetta et al (1990) for DM yield. Gentinetta et al (1990) also pointed out the reduction of general combining ability and specific combining ability mean-squares within a diallel of $b m 3$ hybrids compared with normal hybrids. This might also be compared with the outcome of the search for genes modifying the Opaque 2 gene expression by Vasal et al (1980) within different normal genetic backgrounds.

Genotype $\times$ environment interactions could not be investigated from these experiments. However, data from the FAO silage maize European network (Deinum, 1986) showed a consistent ranking of hybrids in digestibility across 16 experimental fields located between Sweden and Greece, indicating no important genotype $x$ environment for digestibility traits. According to Struik (1986), both cell-wall content and cell-wall digestibility were related to the physiological age of the plants, but the year-to-year variations in cell-wall digestibility were small. Only the lignin content appeared around 1 percent unit lower in cold conditions, compared with hot ones. Cone and Engels (1990) also pointed out that higher temperature conditions induced higher lignin deposition, and decreased the digestibility of maize cell walls. Moreover, temperatures were never a limiting factor during the summer season in Lusignan. So, adjusted means for quality traits, performed including a year effect, might be only very slightly biased due to the lack of an investigation of the genotype $\times$ year interactions.

\section{Normal and bm1 hybrids}

When sheep were fed silage (table II), bm1 hybrids were intermediate between normal and bm3 hybrids for DOM, DCF, and intake. The grain content of $b m 1$ hybrids was intermediate between normal and $b m 3$ hybrids, but 
Table II. Feeding and agronomic traits of normal, bm1 and bm3 hybrids.

\begin{tabular}{|c|c|c|c|c|c|c|c|c|c|c|c|c|c|c|}
\hline Hybrid & $\begin{array}{l}\text { Year of } \\
\text { registration }\end{array}$ & $\begin{array}{l}\text { No of } \\
\text { silos }\end{array}$ & $\begin{array}{c}D O M \\
\%\end{array}$ & $c l$ & $\begin{array}{c}D C F \\
\%\end{array}$ & $c l$ & $\begin{array}{c}\text { Crude } \\
\text { fiber } \\
\% D M\end{array}$ & $d$ & $\begin{array}{c}\text { Intake } \\
g / \\
\mathrm{kgw}^{0.75}\end{array}$ & cl & $\begin{array}{l}\text { Yield } \\
t \text { DM/ } \\
\text { ha }\end{array}$ & $c l$ & $\begin{array}{l}\text { Grain } \\
\% D M\end{array}$ & $c l$ \\
\hline INRA260 & 1961 & 51 & 70.8 & 0.6 & 54.0 & 1.7 & 18.5 & 0.5 & 50.6 & 1.5 & 12.6 & 0.5 & 42.5 & 1.2 \\
\hline INRA260 bmI & & 13 & 71.9 & 1.0 & 58.1 & 3.0 & 19.3 & 1.0 & 52.0 & 2.8 & 12.6 & 0.9 & 42.7 & 2.2 \\
\hline INRA260 $\mathrm{bm} 3$ & & 27 & 73.3 & 0.8 & 62.2 & 2.2 & 18.9 & 0.7 & 51.4 & 2.1 & 11.7 & 0.6 & 42.1 & 1.7 \\
\hline LG11 & 1970 & 74 & 71.0 & 0.5 & 53.1 & 1.4 & 18.3 & 0.4 & 52.0 & 1.3 & 12.3 & 0.4 & 43.4 & 1.0 \\
\hline LG11 bm 1 & & 18 & 72.4 & 0.9 & 60.4 & 2.6 & 19.3 & 0.8 & 53.9 & 2.4 & 11.9 & 0.7 & 44.1 & 1.9 \\
\hline LG11 bm3 & & 28 & 74.0 & 0.7 & 64.4 & 2.0 & 18.7 & 0.7 & 51.8 & 1.9 & 11.3 & 0.6 & 42.7 & 1.5 \\
\hline INRA240 & 1972 & 4 & 72.6 & 1.8 & 59.9 & 5.3 & 17.9 & 1.7 & 56.8 & 4.9 & 12.0 & 1.5 & 48.5 & 3.9 \\
\hline INRA240 bm 1 & & 4 & 74.7 & 1.9 & 60.4 & 5.4 & 17.8 & 1.7 & 49.3 & 5.0 & 12.1 & 1.5 & 44.7 & 4.0 \\
\hline INRA240 $b \mathrm{~m} 3$ & & 8 & 75.0 & 1.3 & 60.9 & 3.8 & 17.9 & 1.2 & 53.9 & 3.5 & 11.6 & 1.1 & 42.7 & 2.8 \\
\hline Mean normal & & 129 & 71.5 & 0.3 & 55.7 & 0.9 & 18.2 & 0.3 & 53.1 & 0.8 & 12.3 & 0.3 & 44.8 & 0.7 \\
\hline Mean $b m 1$ & & 35 & 73.0 & 0.6 & 59.6 & 1.7 & 18.8 & 0.6 & 51.7 & 1.6 & 12.2 & 0.5 & 43.8 & 1.3 \\
\hline Mean $b m 3$ & & 64 & 74.1 & 0.4 & 62.5 & 1.3 & 18.5 & 0.4 & 52.4 & 1.2 & 11.2 & 0.4 & 42.5 & 0.9 \\
\hline
\end{tabular}

DOM: digestibility of organic matter; DCF: digestibility of crude fiber; $\mathrm{cl}=$ confidence limit.

DM yield did not differ for normal and $b m 1$ hybrids. Crude fiber content was similar for the 3 types. From experiments with young bulls (table III), intake of INRA 260 silage was $7 \%$ higher for the $b m 1$ genotype, but $12 \%$ higher for the bm3 one. The average higher intake of maize during the normal/bm1 experiment, compared with the normal/bm3 ones, might be related to the environmental conditions, and only slightly to the breed of bulls fed silage; the appetite of Salers or Charolais bulls is similar when their weights are similar, but the average live weight of Charollais bulls was $25 \mathrm{~kg}$ higher than that of crossbred animals. Observations on average daily body and carcass weight gain showed that INRA260 $b m 1$ had only a little higher feed efficiency than the normal hybrid, 10 and $5 \%$ higher respectively, while INRA $260 \mathrm{bm} 3$ was 24 and $18 \%$ more efficient. From the literature review of Barrière and Argillier (1993), no comparison between normal, bm 1 and $b m 3$ hybrids were found with cattle, but in vitro results ranked bm3 hybrids as having a higher digestibility than $b m 1$ and normal hybrids, bmt hybrids often being closer to normal hybrids than to $b m 3$. Thus, our in vivo experiments were consistent with previous in vitro ones. Despite its lower adverse effect on agronomic characteristics of hybrids, the $b m 1$ allele did not appear to be of any interest in improving the maize silage feeding value.

\section{Biochemical results}

\section{Normal and bm3 hybrids}

The decrease in lignin content due to the $b m 3$ gene was similar for the 3 hybrids (table IV), despite their variation for susceptibility to root and stalk lodging. Even though the statistical significance of effects was not tested, it is worth noticing that, of the 3 hybrids investigated, the most resistant to lodging and stalk breakage (Adonis) was also the hybrid with

Table III. Comparative feeding value with young bulls of normal, bm1 and bm3 INRA 260.

\begin{tabular}{|c|c|c|c|c|c|c|}
\hline & \multicolumn{3}{|c|}{ bm1 experiment ${ }^{a}$} & \multicolumn{3}{|c|}{ bm3 experiments ${ }^{b}$} \\
\hline & normal & bm1 & bm1-normal & normal & bm3 & bm3-normal \\
\hline Silage maize intake $(\mathrm{kg} \mathrm{DM} / \mathrm{d})$ & 8.10 & 8.66 & 0.56 & 7.30 & 8.18 & 0.88 \\
\hline Diet intake $(\mathrm{kg} \mathrm{DM} / \mathrm{d})$ & 9.22 & 9.78 & 0.56 & 8.27 & 9.15 & 0.88 \\
\hline Average daily gain ( $g / d$, body weight) & 1317 & 1447 & 130 & 1187 & 1476 & 289 \\
\hline Average daily gain ( $g / d$, carcass weight) & 725 & 764 & 39 & 762 & 899 & 137 \\
\hline
\end{tabular}

${ }^{a}$ Experiment at INRA Lusignan 1986 (154 d, 12 animals per genotype); ${ }^{b}$ average values of 3 experiments at INRA Lusignan 1976-80 (average length $158 \mathrm{~d}, 24$ animals per genotype (from Malterre et al, 1985)). Agronomic and feeding value characteristics of silages are given in table II. 
Table IV. Biochemical characteristics of lignin of normal, bm3 and $b m 1$ hybrids. ${ }^{a}$

\begin{tabular}{|c|c|c|c|c|c|c|c|c|}
\hline & Lignin $^{\mathrm{b}}$ & $P C^{C}$ & $F e^{d}$ & $P c / F e^{e}$ & $G^{f}$ & $S^{f}$ & 5-OHG' & $S / G^{g}$ \\
\hline LG11 & 15.9 & 126 & 28 & 4.6 & 355 & 391 & & 1.10 \\
\hline LG11 bm3 & 12.0 & 73 & 33 & 2.2 & 390 & 132 & 41 & 0.34 \\
\hline Puma & 16.3 & 120 & 26 & 4.6 & 371 & 358 & & 0.96 \\
\hline Puma $b m 3$ & 12.7 & 66 & 31 & 2.2 & 390 & 115 & 26 & 0.29 \\
\hline Adonis & 17.1 & 117 & 24 & 4.8 & 387 & 346 & & 0.89 \\
\hline Adonis $b m 3$ & 12.8 & 60 & 29 & 2.1 & 433 & 106 & 40 & 0.24 \\
\hline $\mathrm{F} 7 \times \mathrm{F} 2$ & 16.0 & 117 & 25 & 4.8 & 274 & 297 & & 1.08 \\
\hline $\mathrm{F} 7 \times \mathrm{F} 2 b m 1$ & 12.6 & 43 & 23 & 1.8 & 82 & 106 & & 1.29 \\
\hline
\end{tabular}

${ }^{a}$ Separate experiments for normal/bm3 and normal/bm 1 comparisons, average values of bottom, middle and top internodes; blignin measured according to the Klason method (\% cell-wall residue); ${ }^{c} \mathrm{Pc}$ : para-coumaric acid ( $\mu$ mol/g cell-wall residue); ${ }^{d} \mathrm{Fe}$ : ferulic acid $\left(\mu \mathrm{mol} / \mathrm{g}\right.$ cell-wall residue); ${ }^{~} \mathrm{Pc} / \mathrm{Fe}$ : ratio between the 2 hydroxycinnamic acids; 'guaiacyl (G), syringyl (S) and 5-hydroxyguaiacyl (5-OHG) units ( $\mu \mathrm{mol} / \mathrm{g}$ Klason lignin); ${ }^{9} \mathrm{~S} / \mathrm{G}$ : ratio between syringyl and guaiacyl units.

the highest lignin content. The ratio and content of alkali-labile hydroxycinnamic acids behaved similarly for the 3 hybrids, with a slight tendency to a lower release in Adonis. Structural studies of lignin, after thioacidolysis, strengthened the results previously obtained. There was a clear decrease of syringyl units, and the occurrence of the 5-hydroxyguaiacyl residue, corresponding to the decrease of the second step of methoxylation, as reported by Lapierre et al (1988), and in agreement with the enzymatic studies of Grand et al (1985). However, the decrease in syringyl units in the bm3 hybrids was not balanced by an equivalent amount of 5-hydroxyguaiacyl units, and/or a higher content of guaiacyl units. The total yields of monomers involved in aryl-alkylether linkages were lower for the $b m 3$ lignin than for the normal lignin. The lignin of $b m 3$ genotypes appeared as a more condensed polymer than that of the normal types. Even if there were probably some differences in lignin content and structure between hybrids, these results established that the $b m 3$ gene worked similarly within these 3 genotypes, which differ significantly for their DM yield and standability. Variation of lignin content and composition between internodes was also observed by Chabbert et al (1993).

\section{Normal, bm1 and bm3 hybrids}

Based on observation of only one $b m 1$ hybrid, the decrease of lignin content appeared the same between normal and bm1 hybrid as between normal and bm3 hybrids. Previous studies sometimes reported similar results, but most often the lignin content of bm1 plants is intermediate between normal and $b m 3$ plants, as pointed out by Barrière and Argillier (1993). The lower yield of para-coumaric acid, and the equal yield of ferulic acid after alkaline hydrolysis of $b m 1$ and normal material were in good agreement with the study of Kuc and Nelson (1964). The decrease of para-coumaric yield was larger here, and appeared more important in this $b m 1$ hybrid than the $b m 3$ hybrids. During thioacidolysis, lignin units involved in $\beta-O-4$ aryl-ether linkages give rise to specific monomers. The release of monomeric syringyl units was similar between bm1 and $b m 3$, about $30 \%$ of their normal counterpart. But it was very different for guaiacyl units, with a large decrease of the release of these units from the $b m 1$ hybrid. The ratio between syringyl and guaiacyl units was about 0.3 for bm3 hybrids and about 1.3 for the $b m 1$ hybrid. As thioacidolysis cannot cleave C-C linkages referred to condensed bonds in lignin, the yield of lignin-derived units by this method reflects the frequency of $\beta-O-4$ bonds (uncondensed). Consequently the lignin of this bm1 hybrid appeared as a very condensed polymer compared with the normal type. Thus, from these results, the syringyl/guaiacyl ratio, and the more or less condensed linkage in the lignin polymer, appeared specific in each brown-midrib bm1 and $b m 3$ allele.

\section{Relationships between biochemical characteristics and feeding value}

Using animal comparisons of normal, bm1 and bm3 genotypes, it was demonstrated that only the $b m 3$ gene significantly increased the feed- 
ing value of silage maize hybrids. Although only one $b m 1$ hybrid was observed, $b m 1$ and $b m 3$ hybrids differed only in their release of guaiacyl units after thioacidolysis. The ratio between syringyl and guaiacyl units was higher than or equal to 1.0 for the normal and the $b m 1$, and near 0.3 for the $b m 3$. The lignin content and the para-coumaric/ferulic acids ratios obtained after alkaline hydrolysis of the cell walls are not consistent with the ranking of these genotypes in their feeding value. But, until now, these changes in lignification pattern could not be properly discussed in relation to the variations found in digestibility, due to the lack of a cytological comparison of the lignification in cell-wall layers of the $b m 1$ and normal maize lines. Assuming, in agreement with the data of Sarkanen and Ludwig (1971) and Terashima et al (1986), that the guaiacyl lignin type occurs mainly in cell-wall corners and primary wall layers, it can be suggested that the relatively lower digestibility of $b m 1$, compared with bm3 hybrids, could be explained by the high condensation degree of the bm1 lignin. This would allow a higher resistance of primary cell walls and corresponding tissues to mechanical disruption. Further studies on the cytochemistry of lignification are required to conclude that here there was a relation between cause and effect. However, Grenet and Barry (1991) showed that, after $24 \mathrm{~h}$ in the rumen, the parenchyma of bm3 plants degraded faster and the secondary walls of its vascular bundles were disrupted whereas those of normal maize remained intact. Finally, a large amount of ester-bound para-coumaric acids has often been correlated to a decreased digestibility of grass cell walls (Jung, 1989). Although the $b m 1$ hybrid contained a very low amount of bound para-coumaric acid in comparison with normal and $b m 3$ hybrids, the association of phenolic acids within the highly condensed $b m 1$ lignin polymer might also contribute to the enhanced resistance of $b m 1$ cell walls towards degradation.

\section{Comparative interest of the normal and bm3 methods for silage maize improvement}

The highest DOM were observed with few normal hybrids (table $\mathrm{V}$ ), for instance $76.0 \%$ for W79a $\times$ F1254, compared with $74.8 \%$ for Brufix $b m 3$, even though this difference was not significant according to the 2 confidence

Table V. Feeding and agronomic traits of normal early and medium early hybrids illustrating the whole range of observed variation for digestibility of organic matter.

\begin{tabular}{|c|c|c|c|c|c|c|c|c|c|c|c|c|c|c|}
\hline Hybrid & $\begin{array}{c}\text { Year } \\
\text { of } \\
\text { registra- } \\
\text { tion }\end{array}$ & $\begin{array}{c}\text { No of } \\
\text { silos }\end{array}$ & $\begin{array}{c}D O M \\
\%\end{array}$ & $c l$ & $\begin{array}{c}D C F \\
\%\end{array}$ & $c l$ & $\begin{array}{c}\text { Crude } \\
\text { fiber } \\
\% D M\end{array}$ & $c l$ & $\begin{array}{c}\text { Intake } \\
g / \mathrm{kgw}^{0.75}\end{array}$ & $c l$ & $\begin{array}{l}\text { Yield } \\
\text { t DMha }\end{array}$ & $\mathrm{cl}$ & $\begin{array}{l}\text { Grain } \\
\% D M\end{array}$ & $c l$ \\
\hline Rh162 & 1990 & 4 & 64.2 & 1.9 & 44.6 & 5.5 & 20.7 & 1.8 & 44.2 & 5.1 & 15.7 & 1.6 & 38.1 & 4.0 \\
\hline Rh84 & 1977 & 2 & 66.1 & 2.6 & 49.2 & 7.6 & 19.4 & 2.5 & 55.1 & 7.1 & 12.4 & 2.2 & 38.4 & 5.6 \\
\hline Priam & 1987 & 2 & 67.6 & 2.6 & 45.6 & 7.5 & 19.0 & 2.4 & 55.4 & 7.0 & 15.6 & 2.2 & 37.9 & 5.6 \\
\hline Mammouth & 1982 & 6 & 68.5 & 1.6 & 50.9 & 4.5 & 20.2 & 1.4 & 47.7 & 4.2 & 16.3 & 1.3 & 42.6 & 3.3 \\
\hline Rh164 & 1992 & 4 & 68.9 & 1.9 & 56.4 & 5.5 & 24.1 & 1.8 & 44.7 & 5.1 & 15.5 & 1.6 & 40.2 & 4.0 \\
\hline Ascot & 1988 & 6 & 69.4 & 1.6 & 55.6 & 4.5 & 21.2 & 1.5 & 49.8 & 4.2 & 14.0 & 1.3 & 39.9 & 3.3 \\
\hline Briard & 1988 & 4 & 70.4 & 1.9 & 53.2 & 5.5 & 20.3 & 1.8 & 48.6 & 5.1 & 15.1 & 1.6 & 42.8 & 4.0 \\
\hline Dekalb250 & 1986 & 9 & 71.1 & 1.3 & 53.4 & 3.8 & 19.2 & 1.2 & 49.1 & 3.5 & 12.6 & 1.1 & 44.6 & 2.8 \\
\hline Brutus & 1978 & 6 & 71.4 & 1.6 & 54.8 & 4.7 & 19.8 & 1.5 & 46.4 & 4.4 & 12.4 & 1.3 & 39.7 & 3.5 \\
\hline Dea & 1980 & 32 & 71.5 & 0.7 & 53.0 & 2.1 & 18.4 & 0.7 & 50.5 & 2.0 & 14.2 & 0.6 & 45.6 & 1.6 \\
\hline Lixis & 1985 & 16 & 72.3 & 1.0 & 55.4 & 3.0 & 18.4 & 1.0 & 47.3 & 2.8 & 14.1 & 0.9 & 41.1 & 2.2 \\
\hline Rh167 & 1987 & 4 & 72.4 & 1.9 & 51.4 & 5.5 & 16.6 & 1.8 & 50.2 & 5.1 & 16.1 & 1.6 & 47.0 & 4.0 \\
\hline Castel & 1986 & 4 & 72.7 & 1.9 & 56.8 & 5.4 & 19.4 & 1.7 & 49.8 & 5.0 & 13.0 & 1.5 & 36.7 & 4.0 \\
\hline Rh174 & 1991 & 2 & 73.3 & 2.6 & 50.4 & 7.5 & 18.9 & 2.4 & 52.1 & 7.0 & 11.7 & 2.2 & 45.2 & 5.6 \\
\hline $\mathrm{F} 7 \times \mathrm{W} 117$ & Ex 1974 & 1 & 74.4 & 3.6 & 64.0 & 10.4 & 17.3 & 3.4 & 54.8 & 9.6 & 10.4 & 3.0 & 53.4 & 7.7 \\
\hline $\mathrm{A} 374 \times \mathrm{F} 1254$ & Ex 1978 & 2 & 74.5 & 2.7 & 62.6 & 7.8 & 19.2 & 2.5 & 52.3 & 7.2 & 12.3 & 2.2 & 51.2 & 5.8 \\
\hline Ep $1 \times W 117$ & Ex 1974 & 1 & 75.7 & 3.6 & 61.9 & 10.4 & 16.9 & 3.4 & 42.9 & 9.6 & 10.6 & 3.0 & 51.5 & 7.7 \\
\hline W79a $\times F 1254$ & Ex 1978 & 2 & 76.0 & 2.7 & 61.0 & 7.8 & 17.3 & 2.5 & 52.5 & 7.2 & 12.6 & 2.2 & 52.0 & 5.8 \\
\hline
\end{tabular}

DOM: digestibility of organic matter; DCF: digestibility of crude fiber; $\mathrm{cl}=$ confidence limit. 
limits. This demonstrated that some normal hybrids might have as high a DOM as bm3 hybrids. For DCF, the highest values were similar for the best normal and bm3 hybrids. But grain contents were about 10 points higher for the best normal hybrids than for the best $b m 3$ ones, while the DOM was only approximately 1 or 2 points higher, with equivalent values for DCF. Furthermore, cell-wall constituents are probably better digested when the starch content is lower in the diet, as was reported by El-Shazy et al (1961), Henning et al (1980) and Joanning et al (1981). This is also in agreement with results of the effect of grain content on the milk yield of dairy cows (Barrière and Emile, 1990). The decrease of the grain content of silage from 48 to $41 \%$, after discarding $1 / 4$ of the ears at harvest, had no effect on milk yield and quality, or on feed efficiency (Emile and Barrière, 1992). Thus, bm3 hybrids would probably be more efficient in cattle nutrition than normal hybrids with an equal DOM.

Struik (1983) had compared 19 hybrids of the Dutch recommended list released between 1969 and 1983; newly registered varieties were generally less digestible than the older ones. This result was not specifically confirmed by Barrière et al (1992) studying a broader genetic basis. There was no clear correlation between the year of registration and the DOM or the DCF, but many of the worst values were observed with more recently registered hybrids. For instance, Rh 162, a new medium early high-yielding hybrid with good standability, had poor DOM and DCF. The drift of maize hybrids towards low feeding values is probably more related to stalk rot and breakage resistance improvement, rather than to lodging resistance improvement. Breeding for silage maize, instead of breeding for grain maize used for silage, will probably allow the release of hybrids with a good resistance to lodging, a high digestibility, and a sufficient tolerance to stalk rot. Results obtained with Adonis and Adonis bm3 also proved the possibility of a large improvement of digestibility when using the $b m 3$ gene. Backcrosses for $b m 3$ conversion of parent lines of hybrids such as Rh 162 has begun this year, to test the hypotheses that: i) improvement of DOM by the bm3 gene is all the more important when the value of the investigated hybrid is lower; and ii) the agronomic value of the bm3 hybrid remains higher when the normal hybrid is more impressive. Standabil- ity, and probably DM yield, of the $b m 3$ counterpart is indeed correlated with that of the normal hybrid, even though all agronomic problems induced by the bm3 gene, such as reduced earliness, are not solved. However, a small decrease in DM yield is probably acceptable, subject to a significant improvement of the feeding value, especially because available cropping areas might not be the limiting factor of economical performance for cattle breeders in the near future.

\section{CONCLUSIONS}

Despite its lower adverse effects on agronomic traits, the brown-midrib gene bm1 had probably no interest for silage maize breeding, because of its low ability to improve the zootechnic performances of cattle. A rather large variation of effects on digestibility, intake, yield, and grain content was found when the bm3 was backcrossed into different maize genotypic backgrounds. Notably, a large improvement of digestibility might be expected for its use with very high yielding and standable hybrids, the digestibility of which often appeared low. From the biochemical characterization of various $b m 3$ hybrids, it appeared that the effect on lignin content and composition was similar, despite the different genetic background. The observed values of DOM allow us to make the assumption that the improvement of digestibility by the $b m 3$ gene could reach a DOM of almost $74 \%$ in hybrids, quite independently of their original value.

The higher digestibility of a plant cell wall is probably mainly due to its susceptibility to be rapidly disrupted by rumen microorganisms. The bm3 gene was the only one increasing significantly the feeding value of silage maize hybrids; correlatively, only the lignin of $b m 3$ plants had a low syringyl/guaiacyl ratio after thioacidolysis. The lignin content and the para-coumaric/ferulic acids ratios obtained after alkaline hydrolysis of the cell walls are not consistent with the ranking of these genotypes for their feeding value. The lignin of $b m 1$ plants was probably a more condensed polymer than the lignin of $b m 3$ ones. Moreover, cytological comparisons of the lignification in cell-wall layers are required before connecting reliably these patterns in lignifica- 
tion and feeding values. No conclusion could be drawn from the variation in feeding value between normal hybrids, because their patterns in phenolic acids and lignin monomeric units are not known. But increases in lignin content and/or bound phenolic acids content are well-known factors inducing a decrease of plant digestibility. The patterns of secondary cell-wall lignification act upon the susceptibility of the tissue to be disrupted. The paracoumaric and ferulic acids are involved in linkage with lignin and/or hemicellulose; ferulic acid might act as a bridge linking lignins to arabinoxylan residues of hemicelluloses (Jung, 1989; liyma et al, 1990). Thus, the content and composition of phenolic components of the cell wall, characteristics whose variation was clearly pointed out in studies of brownmidrib hybrids, are worth investigating as potential criteria in breeding maize for feeding value purposes.

A large variation for digestibility was found among normal hybrids, and its use might allow significant improvement of the feeding value of varieties. However, old inbred lines inducing high digestibility often included unfavorable agronomic traits, such as poor yield or susceptibility to lodging or stalk rotting. However, second or third cycle lines following pedigree breeding might combine all traits, even though stalk standability and stalk digestibility are partly antagonistic. This method may be considered as easier than the $b m 3$ one, but at present, the 2 methods are probably complementary, and worth investigating. Moreover, Chabbert et al (1993b) observed in bm2 materials a very high ratio between syringyl and guaiacyl units, with a lignin content of bm2 cell walls similar to bm3 ones, and a para-coumaric/ferulic ratio a little lower for bm2 than for normal, but higher than for bm3 cell walls. Furthermore, through allelism tests with original US brown-midrib materials at INRA Lusignan, we identified the DB5884 $b m 3 \times S 72 b m 3$ hybrid, received from the Bernburg institute (Köhler et al, 1989, 1990) as a $b m 2$ one. Thus, from a theoretical point of view, comparisons of biochemical and feeding value of normal and $b m 3$ hybrids, differing mostly for the DOM or DCF of the normal counterparts, and comparisons of $b m 1, b m 2$ and $b m 3$ hybrids, are most certainly a major route to the understanding of relationships between lignification and feeding value, and relationships between the cell-wall constituents. Cloning enzymes involved in the biosynthesis of lignin (Collazo et al, 1992) and using antisense RNA techniques, cloning and sequencing brown-midrib loci of normal and mutant genotypes could also be powerful tools towards understanding the lignification and the working of brown-midrib genes.

\section{ACKNOWLEDGMENTS}

This work was partly supported by a grant from the INRA network AIP Agrobiolignification. The authors are thankful to all contributors to these experiments, especially A Gallais, who began the work with brown-midrib genes at INRA Lusignan, $R$ Traineau, $H$ Berthet, L Huguet, JC Emile and M Lila. We thank $M$ Rives for his criticisms. We also acknowledge $A$ de Pourtalès for the linguistic revision of the manuscript.

\section{REFERENCES}

Barrière $Y$, Emile JC (1990) Effet des teneurs en grain et de la variabilité génétique sur la valeur énergétique du maïs ensilage mesurée par des vaches laitières. agronomie 10, 201-221

Barrière Y, Traineau R, Emile JC, Hébert Y (1992) Variation and covariation of silage maize digestibility estimated from digestion trials with sheep. Euphytica 59, 61-72

Barrière $Y$, Argillier $O$ (1993) Brown-midrib genes of maize, a review. agronomie 13, 865-876

Chabert B, Tollier MT, Monties B, Barrière $\mathrm{Y}, \mathrm{Ar}$ gillier O (1993) Biological variability in lignification of maize. Part 1: Brown-midrib bm3 expression in three maize cultivars. J Sci Food Agric (sous presse)

Chabbert B, Tollier MT, Monties B, Barrière Y, Argillier $O$ (1993b) Biological variability in lignification of maize. Part 2: Expression of the brown-midrib 2 mutation. $J$ Sci Food Agric (sous presse)

Chesnot M, Martin-Rosset W (1985) Comparaison entre espèces (mouton, cheval, bovin) de la digestibilité et des quantités ingérées des fourrages verts. Ann Zootech 34, 291-312

Collazo P, Montoliu L, Puigdomènech P, Rigau J (1992) Structure and expression of the lignin $O$ methyltransferase gene from Zea Mays L. Plant Mol Biol 20, 857-867

Cone JW, Engels FM (1990) Influence of growth temperature on anatomy and in vitro digestibility of maize tissues. J Agric Sci Camb 114, 207-212 
Deinum B (1986) Genetic and environmental variation in digestibility of forage maize in Europe. In: FAO report of the subnetwork: the nutritive value of the whole maize plant (B Deinum, ed). Agricultural University of Wageningen, $38 p$

Dudley JW, Lambert RJ, Alexander DE (1974) Seventy generations of selection for oil and protein concentration in the maize kernel. In: Seventy generations of selection for protein and oil in the maize. Crop Sc Soc Am, Madison, Wisconsin, 181-212

El-Shazy K, Dehority BA, Johnson RR (1961) Effect of starch on the digestion of cellulose in vitro and in vivo by rumen microorganisms. J Anim Sci 20, 268-273

Effland MJ (1977) Modified procedure to determine acido-insoluble lignin in wood and pulp. Tappi $60,143-144$

Emile JC, Barrière $Y$ (1992) Effets de la teneur en grain de l'ensilage de maïs sur les performances zootechniques de vaches laitières. Prod Anim 5, 113-120

Gentinetta E, Bertolini M, Lorenzoni C, Motto M (1990) Effect of brown-midrib-3 mutant on forage quality and yield in maize. $J$ Genet Breed 44, 21-26

Grand C, Parmentier P, Boudet A, Boudet AM (1985) Comparison of lignins and of enzymes involves in lignification in normal and brown-midrib (bm3) mutant corn seedlings. Physiol Veg 23, 905-911

Grenet E, Barry P (1991) Microbial degradation of normal maize and $b m 3$ maize in the rumen observed by scanning electron microscopy. J Sci Food Agric 54, 199-210

Gupta HO, Joginder-Singh, Jain OP (1988) Brown midrib colour as an index of forage quality in maize (Zea mays L.). Proc Ind Nat Sci Acad B Biol Sci 54, 175-178

Hoden $A$, Barrière $Y$, Gallais $A$, Huguet $L$, Journet $M$, Mourguet $A$ (1985) Le maïs brown midrib plante entière. 3. Utilisation sous forme d'ensilage par les vaches laitières. Bull Tech CRZV Theix INRA 60, 43-58

liyama K, Bach Tuyet Lam T, Stone BA (1990) Phenolic acid bridges between polysaccharides and lignin in wheat internodes. Phytochemistry 39 , 733-737

Jarrige R (1988) Alimentation des bovins, ovins et caprins, ed (INRA Paris), $471 p$

Joanning SW, Johnson DE, Bary BP (1981) Nutrient digestibility depressions in corn silagecorn grain mixtures feed to steers. J Anim Sci 53, 1095-1103

Jung HG (1989) Forage lignins and their effects on fibre digestibility. Agron $J$ 81, 33-38

Kölher R, Leuoth A, Jeroch H, Flachowsky G, Gebhardt G, Hielscher H, Kappel W (1989) Untersuchungen in Restpflanzen verschiedener
Maishybriden. Arch Anim Nutr, Berlin 39, $187-$ 192

Köhler R, Jeroch H, Flachowsky G, Gebhardt G, Hielscher H, Kappel W (1990) Futtermittelkundliche Bewertung verschiedener Maisgenotypen. Arch Anim Nutr, Berlin 40, 167-274

Kuc J, Nelson OE (1964) The abnormal lignins produced by the brown-midrib mutants of maize. 1. The brown-midrib-1 mutant. Arch Biochem Biophys 105, 103-113

Henning PA, van der Linden $Y$, Mattheyse ME, Nauhaus WK, Schwartz HM (1980) Factors affecting the intake and digestion of roughage by sheep fed maize straw supplemented with maize grain. J Agric Sci Camb 94, 565-573

Lapierre C, Monties B, Rolando C (1986) Thioacidolysis of poplar lignins: identification of monomeric syringyl products and characterization of guaiacyl-syringyl lignin fractions. Holzforschung 40, 113-118

Lapierre C, Tollier MT, Monties B (1988) Mise en évidence d'un nouveau type d'unité constitutive dans les lignines d'un mutant de maïs bm3. $C R$ Acad Sci Paris, Sér III, 723-728

Malterre C, Bertin G, Gallais A, Huguet L, Micol D (1985) Le maïs brown midrib plante entière. 2. Utilisation sous forme d'ensilage par les taurillons. Bull Tech CRZV Theix INRA 60, 4358

Miku V, Komarova GE, Rotar Al (1980) Genetic variation in lignin content in maize. Doklady Vsesoyuznoi Ordena Lenina i Ordena Trudovogo Krasnogo Znameni Akademii Sel'skokhozaïstvennykh Nauk Imeni VI Lenina 9, 9-10 (in Russian)

Moran JB, Lemerle C, Trigg TE (1988) The intake and digestion of maize silage-based diet by dairy cows and sheep. Anim Feed Sci Technol $20,299-312$

Sarkanen KV, Ludwig CH (1971) Lignins, Occurrence, Formation, Structure and Reactions. Wiley-Interscience, New York

Struik PC (1983) Physiology of forage maize (Zea mays $\mathrm{L}$ ) in relation to its production and quality. Thesis, Agricultural University of Wageningen, $252 \mathrm{pp}$

Terashima M, Kazuhito F, Satoshi T (1986) Heterogeneity in formation of lignin. II. An autoradiography study on the formation of guaiacyl and syringyl lignin in poplar. J Wood Chem Technol 6, 495-504

Vasal SK, Villegas E, Bjarnason M, Gelaw B, Goertz P (1980) Genetic modifiers and breeding strategies in developing hard endosperm Opaque-2 materials. In: Improvement of quality traits of maize for grain and silage use. (WG Pollmer, RH Phipps, eds) Martis Nijhoff, Amsterdam, 37-72 